\title{
工作機械用転がり軸受主軸の工具回転非同期振れによる加工面影響の低減 (加振システムの開発)
}

\author{
正和 裕太 ${ }^{* 1}$ ，吉岡 勇人 ${ }^{* 2}$ ，新野 秀憲*3

\section{Reduction of the influence on machining surface caused by tool non-repeatable run-out of rolling bearing spindle for machine tools (Development of an excitation system)} \\ Yuta SHOWA*1, Hayato YOSHIOKA*2 and Hidenori SHINNO*3 \\ ${ }^{* 1}$ Makino Milling Machine CO., LTD. \\ 4023 Nakatsu, Aikawa-machi, Aiko-gun, Kanagawa 243-0303, Japan

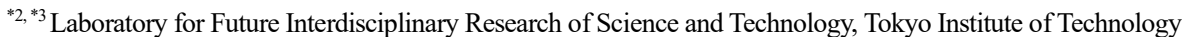 \\ 4259-G2-19 Nagatsuta-cho, Midori-ku, Yokohama-shi, Kanagawa 226-8503, Japan \\ Received: 22 December 2019; Revised: 6 February 2020; Accepted: 9 March 2020

\begin{abstract}
In recent years, the surface quality requirement in die and mold has become severer. In addition, die and mold with surface structure are increasing and it makes polishing process difficult. In order to realize mirror surface finish by cutting, it is necessary to reduce influence of tool non-repeatable run-out (NRRO) on machining surface. Rolling bearings are widely used for machine tools, NRRO of a spindle due to rolling element revolution depends on spindle conditions such as rotational speed, temperature, and cutting load. In order to reduce influence of NRRO on workpiece surface, a prototype of an excitation system which can generate counter excitation force is proposed in this paper. The tool run-out during machining was measured and the results confirmed that the machined surface was affected by this NRRO. In addition, it was confirmed that NRRO has multiple peaks in frequency domain and the state of each peak changes even at the same spindle speed. After developing an excitation system with a voice coil motor, it was confirmed effectiveness of the system that can reduce NRRO component from measured tool run-out signal.
\end{abstract}

Keywords : NRRO, Rolling bearing, Spindle, Machine tools, Excitation, Machining surface, Voice coil motor

\section{1. 緒 論}

近年，主に光学機器および医療機器分野の金型において，製品の高機能化や意匠デザインの高度化に伴う面品 位の向上が求められている。さらに，自動車へッドライトや然料電池セパレータなどのように，表面に微細な形 状パターンが求められるケースも増えている。このような場合，従来のように最終工程の磨き作業で金型表面を 仕上げることは困難である．金型における高品位な表面，いわゆる鏡面を切削加工で達成するためには，これま では問題とならなかった加工機内の様々な微小振動を抑制しなければならない.

切削加工における大きな振動の一つとして，加工に伴い工具が振動するびびり振動が挙げられる．びびり振動 を回避する方法としては，加工条件を変更することが有効であり，安定限界線図(Stability lobe)を用いて安定して 加工できる主軸回転数を選定する方法が広く知られている. また，その他にも動吸振器を追加することで制振す る方法(中野他，2014)や，主軸頭外部にアクチュエータを取り付け，振動を与えることで制振する方法(Kleinwort

No.19-00450 [DOI:10.1299/transjsme.19-00450], J-STAGE Advance Publication date : 19 March, 2020

*1 正員，（株）牧野フライス製作所（干243-0303 神奈川県愛甲郡愛川町中津 4023）

*2 正員，東京工業大学 未来産業技術研究所（干226-8503 神奈川県横浜市長津田町 4259-G2-19)

*3 正員, フェロー, 東京工業大学 未来産業技術研究所

E-mail of corresponding author: showa@makino.co.jp 
et al., 2018), 主軸頭内部にアクチュエータを取り付け, 主軸に変位を与えることで制振する方法(Monnin et al., 2014), 既存の転がり軸受に磁気軸受を追加し，主軸に変位を与えることで制振する方法(van Dijk, 2011)など様々な方法 が提案されている．既存の転がり軸受に磁気軸受を追加寸る方法に関しては，送り軸の反転運動に起因する象限 突起低減への応用も提案されている(Oda et al., 2019).

切削加工におけるもう一つの大きな振動として，主軸および工具の回転振れが挙げられる．主軸および工具の 回転振れとして一般的に論じられるのは回転同期振れ(Repeatable Run-Out, 以下 RRO)であるが，この他に回転非 同期振れ(Non-Repeatable Run-Out，以下 NRRO)が存在する．主軸に取り付けた工具の半径方向の誤差運動は，JIS B6190-7 に従い, 半径方向に配置した二つの変位センサにより測定することができる. 例として, X 軸方向の RRO を $2 \mu \mathrm{m}, \mathrm{X}$ 軸方向の NRRO を $0 \mu \mathrm{m}, \mathrm{Y}$ 軸方向の RRO $2 \mu \mathrm{m}, \mathrm{Y}$ 軸方向の NRRO を $0.2 \mu \mathrm{m}$ とすると, 測定結果 は図 1 のようになる. 図1(a)は二つの変位センサによる測定結果をリサージュ曲線として表したものであり, 主 軸回転による工具の軌跡をそのまま表している，このリサージュ曲線より，Y 軸方向の側面加工を行った場合， 表面粗さは $0.2 \mu \mathrm{m}$ 以上となることがわかる. 測定を任意の一方向に限定した場合は, 図 1(b)のように一つの変位 センサによる測定結果の時間軸での評価や, フーリエスペクトルでの評価も可能である. RRO は一般的に NRRO よりも大きく，測定は容易である．また，主軸および工具の位相に対する再現性があるため，一枚刃の工具を使 用した加工や, RRO を考慮した工具測定など, 対処方法はいくつか考えられる. 一方で, NRRO は一般的に RRO よりも小さく，測定に手間がかかる．また，主軸および工具の位相に対する再現性がないため，主軸回転を伴わ ないへール加工や，刃のない工具を使用した加工といった特殊なものを除き，対処は困難である．なお，本稿で はテストバーではなく加工に使用する工具を測定しているため, 測定結果には工具の真円度などの誤差を含む. よって, “半径方向の誤差運動”ではなく“回転振れ”と記述している. NRRO の低減は仕上げ面の要求面品位が高 いほど重要となるが，NRRO と加工面との関倸性について議論した例は少ない(根深他，2009).

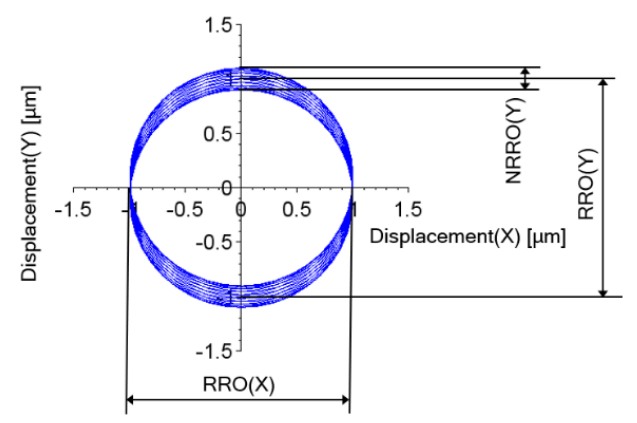

(a) Lissajous curve of rotational tool

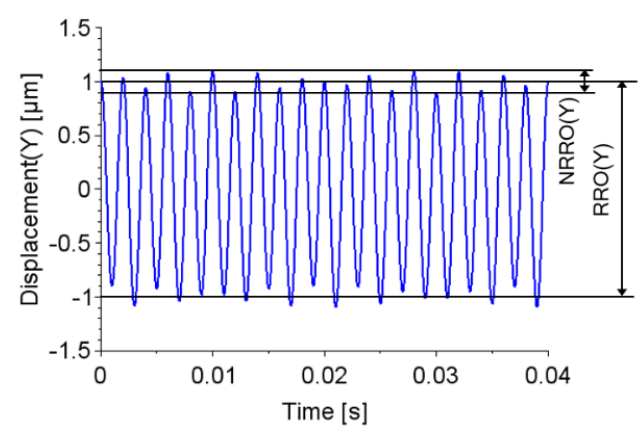

(b) Time base waveform in $\mathrm{Y}$ direction

Fig. 1 Measurement example of tool run-out. Tool run-out is measured by two displacement sensors located radial direction. If limited to one direction, it is possible to measure with one displacement sensor.

NRRO の原因は種々考えられるが，工作機械用主軸の軸受として広く採用されている転がり軸受において，転 動体公転運動に起因する NRRO が存在することが知られている(野口他, 2012). 主軸と同期回転する部品は複数 存在するため, 部品単位ではバランスがとれていたとしても, 主軸の組み立て後ではバランスが崩れることがあ るが，RRO は主軸の組み立て後でもバランスウェイト追加などによって調整可能である．しかし，転がり軸受の 転動体公転運動と同期回転する部品は転動体の保持器のみであり, 転動体や保持器に対してバランス調整を行う ことは困難である．転がり軸受の NRRO は最小限となるよう継続的に改良が続けられており，一般的な加工で は問題ないレベルにまで抑えられているが，鏡面，具体的には表面粗さ数 $\mathrm{nm}$ 数十 $\mathrm{nm}$ を達成しようとした場 合には, この影響を低減しなければならない.このNRRO の原因は転動体ではなく保持器である場合もあるが,

周波数は同じとなるので，切り分けはおこなっていない.

本研究では, 転がり軸受の転動体公転運動に起因寸る NRRO の加工面への影響を低減し, 切削による鏡面加工 を可能にすることを目的とする. そのための手段として, 主軸頭にボイスコイルモータ(Voice Coil Motor, 以下 $\mathrm{VCM}$ )を付与し，相対振動を励起することでテーブルー工具間の相対変位から NRRO 成分を低減する加振システ ムを試作し，効果が得られることを確認した。 


\section{2. 工具回転振れが加工面に与える影響}

転がり軸受の転動体公転運動に起因する NRRO が加工面へ与える影響を確認するため, 立て形マシニングセン タの主軸頭に静電容量形の非接触変位センサ(6504-01 および 6810, MICROSENS)を取り付けて加工中の工具回転 振れを測定し, 三次元光学プロファイラ(Nexview, Zygo)にて測定した被削材の加工面プロファイルとの比較を行 った. 主軸頭, 工具, 非接触変位センサならびに被削材の位置関係を図 2 に，加工条件を表 1 にそれぞれ示す. 加工条件は仕上げ加工を想定したものであり，加工負荷が加工面へ与える影響は十分小さい条件となっている. また，測定した工具回転振れのフーリエスペクトルを図 3 に，加工面プロファイルのフーリエスペクトルを図 4 にそれぞれ示す．図 3 において，500 Hz のピークはRRO，225 Hz のピークは転がり軸受の転動体公転運動に起 因する NRRO に該当する．なお，NRRO はRRO と比べてかなり小さいため，縦軸は対数表示としている.

ボールエンドミルを使用した側面加工において, 理論カスプ高さは以下の式で表される(是田他, 1993).

$$
h=r-\sqrt{r^{2}-\frac{f^{2}}{4}}
$$

ただし, $h$ : カスプ高さ $[\mathrm{mm}], r$ 工具半径 $[\mathrm{mm}], f:$ ピックフィード $[\mathrm{mm}]$ である. 工具に回転振れが全くない と仮定した場合, 表 1 の加工条件における理論カスプ高さは式(1)より $0.32 \mu \mathrm{m}$ となる. 図 4 において, ピックフ イードに該当する $500 \mathrm{~Hz}$ のピークはおおよそ $0.11 \mu \mathrm{m}$ (全振幅換算で $0.22 \mu \mathrm{m}$ ) となっており, 近い值となっている.

図 3 において，500 Hz にRRO のピークがみられるが，このピークは図 4 における $500 \mathrm{~Hz}$ のピーク高さに影響を 与えていない. よって, 高品位な加工面を得るためには, NRRO を低減することが重要であるといえる. ただし, これは工具が一枚刃の場合または多枚刃のうち一刃しか加工面に寄与しない場合に該当する．NRRO の原因は 様々であるが, 本研究では, 転がり軸受の転動体公転運動に起因する NRRO に着目し, 低減方法の検討を行った.

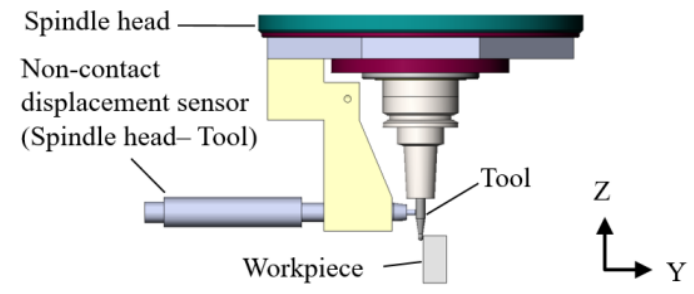

Fig. 2 Tool run-out measurement during milling process. Direction of milling process and measurement are limited to Y-axis direction.

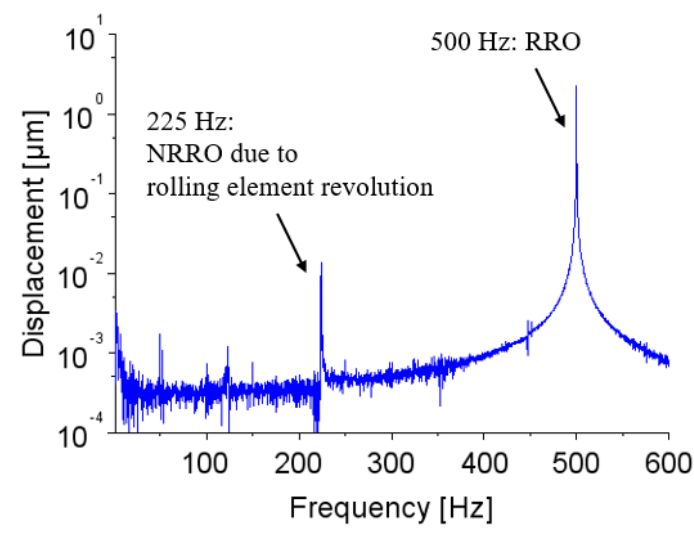

Fig. 3 Fourier spectrum of tool run-out during milling process. A peak at $500 \mathrm{~Hz}$ means RRO. A peak at $225 \mathrm{~Hz}$ means NRRO due to rolling element revolution.
Table 1 Cutting conditions for tool run-out measurement. These conditions are used for finishing process.

\begin{tabular}{|l|c|}
\hline Spindle speed $\left[\mathrm{min}^{-1}\right]$ & 30,000 \\
\hline Tool & $\begin{array}{c}\text { R0.984 Ball endmill } \\
\text { (Single crystal diamond, 1 flute) }\end{array}$ \\
\hline Feed speed $[\mathrm{mm} / \mathrm{min}]$ & (X-axis) \\
\hline Cutting depth $[\mathrm{mm}] \quad$ (Y-axis) & 0.01 \\
\hline Workpiece & A5052 \\
\hline Coolant & Dry \\
\hline
\end{tabular}

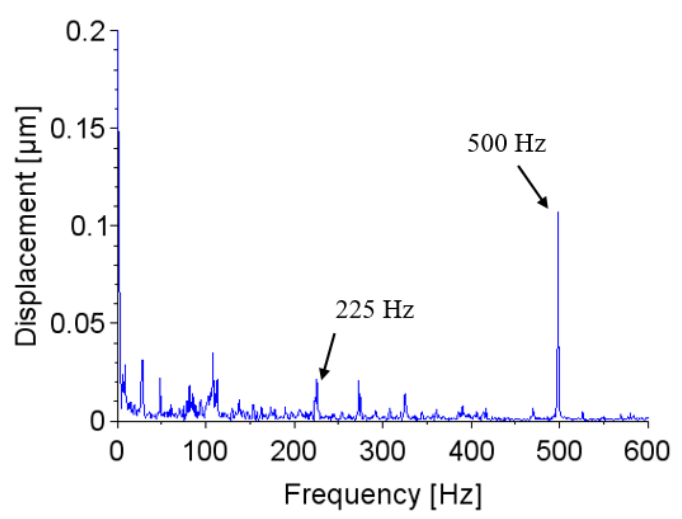

Fig. 4 Fourier spectrum of workpiece surface profile. Effect of RRO was not detected on workpiece surface. 


\section{3. 転がり軸受の転動体公転運動に起因する NRRO}

\section{$3 \cdot 1$ 転がり軸受の転動体公転運動に起因する NRRO の発生原理}

転がり軸受の転動体公転運動に起因する NRRO が発生する理由は, 図 5 のように内輪(または外輪)回転速度と 転動体公転速度が一致しないためである。転動体公転速度は式(2)で表される(野口，畔柳，2007).

$$
n_{c}=\left(1-\frac{D_{w} \cos \alpha}{D_{p w}}\right) \frac{n_{i}}{2}+\left(1+\frac{D_{w} \cos \alpha}{D_{p w}}\right) \frac{n_{e}}{2}
$$

ただし, $n_{c}$ : 転動体公転速度 $\left[\mathrm{min}^{-1}\right], n_{i}$ : 内輪回転速度 $\left[\mathrm{min}^{-1}\right], n_{e}$ : 外輪回転速度 $\left[\mathrm{min}^{-1}\right], D_{w}$ : 転動体直径 $[\mathrm{mm}]$, $D_{p w}$ : 転動体ピッチ直径 $[\mathrm{mm}], \alpha$ : 接触角 $[\mathrm{deg}]$ である. 式中の各パラメータは寸法誤差や形状誤差などわずかに ばらつきを持っており，主軸の回転および発熱によってもパラメータは変化する．さらに，転がり軸受において もわずかに接触面にすべりが存在するため, 高速回転中の NRRO の位相を外部から正確に把握することは困難で ある. また，一般的な工作機械用転がり軸受主軸においては，NRRO はRRO と比べて非常に小さいため，両者 が混在した工具回転振れから NRRO を議論することは難しい.

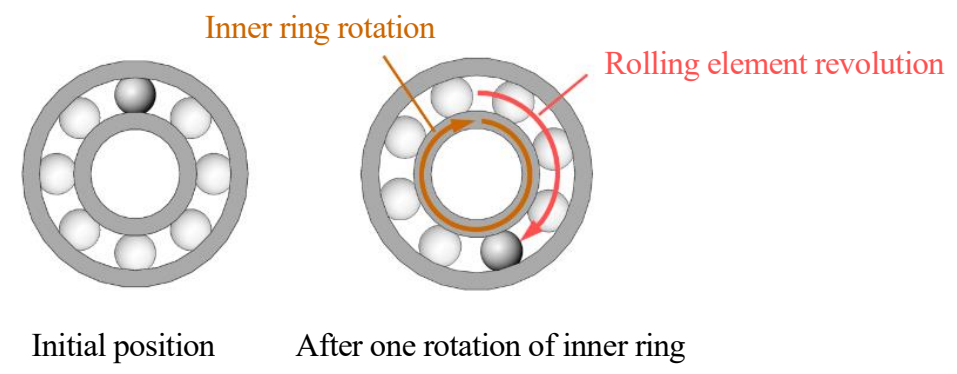

Fig. 5 Difference of inner ring rotation and rolling element revolution.

This difference causes NRRO of tool rotation.

\section{$3 \cdot 2$ 転がり軸受の転動体公転運動に起因する NRRO の測定}

転がり軸受の転動体公転運動に起因する NRRO に関し，軸受単体での評価や二つの軸受を組み合わせた場合の 取り付け誤差影響について評価した報告(野口，金田，2017)はあるが，工作機械用主軸の軸受として転がり軸受を 採用する場合においては，三つ以上の転がり軸受を組み合わせて使用するのが一般的である. また，数万 $\mathrm{min}^{-1}$ と いう高速回転の中で閏滑，発熱，冷却といった複雑な現象にさらされているが，このような条件下での NRROに ついては詳細に議論されていない，そこで，第 2 章に引き続き，主軸回転数を変化させて工具回転振れの測定を 行った.

測定に使用した主軸は，同じ諸元のアンギュラ玉軸受をフロントに背面組み合わせで二列，リアに一列組み込 んでおり，潤滑はアンダーレース方式を採用している．主軸の断面図を図 6 に示す．また，アンギュラ玉軸受の 諸元を表 2 に示寸，第 2 章では，加工の妨げとならないよう非接触変位センサを主軸頭に取り付けたが，本測定 ではより被削材の加工面に近い測定結果を得られるように，非接触変位センサをテーブル上に固定し，工具回転 振れを測定した．工具および非接触変位センサの位置関係を図 7 に示寸.JIS B6190-7 では測定に十分な回転回数 は 20 回転とされているが，詳細に周波数分析を行うため，測定時間は主軸回転数によらず 10 秒間とした．図 3 に示すように，NRRO はRRO と比較してかなり小さいため，時間軸波形での評価は難しい，保存した時間軸波 形から別途フーリエスペクトルを計算する方法は測定効率が悪く，また，リアルタイムで評価するためには高価 な測定器が必要となる。しかし，転がり軸受の転動体公転運動に起因する NRRO のみに着目寸れば，非接触変位 センサの出力にバンドパスフィルタ(Band Pass Filter，以下 BPF)を適用することにより，時間軸波形におけるリア ルタイムでの評価が容易になる. 本稿では, BPF として周波数を任意に設定できるプログラマブルフィルタ $(3625$, NF 回路設計ブロック)を使用して評価を行った．BPFの中心として設定する周波数は式(2)によって求めることが 可能であるが，転がり軸受の寸法誤差や主軸回転による発熱などによって数 $\mathrm{Hz}$ 程度ずれる可能性がある。この 
点については, BPF にある程度の幅の通過帯域を持たせることで対応可能である.ただし, 前述したように NRRO は RRO と比べて非常に小さいため, 今回使用した滅衰傾度-48 dB/oct の BPF では RRO の影響を完全に除去する ことができなかった．よって，最終的にはフーリエスペクトルにおける該当周波数のピークの大きさで評価する こととした. 主軸の回転数はエンコーダの出力で最大 $\pm 0.5 \%$ 変動するが, フーリエスペクトルにおいて RRO に該 当する周波数に鋭いピークが確認できることから，この影響は小さいものと判断した.

測定データとして, 非接触変位センサの出力にノイズ成分除去を目的としたローパスフィルタ(Low Pass Filter, 以下 LPF)を適用したデータと，同出力に NRRO 成分を抽出することを目的とした BPF を適用したデータの 2 種 類を取得した. 主軸回転数 $30,000 \mathrm{~min}^{-1}$ の条件で測定した工具回転振れを図 8 および図 9 にそれぞれ示す. 図 8 お よび図 9 は，主軸回転開始からの経過時間が異なる．LPF を適用した図 8(a)および図 9(a)のデータでは，両者に ほとんど差異がないが, BPF を適用した図 8(b)および図 9(b)のデータでは, 両者に明確な差異が確認できる. BPF を適用したデータからそれぞれフーリエスペクトルを計算すると，図 8(c)および図 9(c)に示すように，転動体公 転周波数付近に三つのピークが存在し, 図 8 の測定時と図 9 の測定時では各ピークの大きさが異なっていること がわかる. 図 9 (c)のように近接する周波数のピークが複数存在する場合, 時間軸波形図 9(b)では両者の差分にあ たる低い周波数成分が存在するように見えるうなりと呼ばれる現象が発生する.この現象は，主軸回転に伴う発 熱により，転がり軸受のパラメータが時間変化したことによって引き起こされたものと考えられる他，転がり軸 受の潤滑状態が影響している可能性も考えられる(野口, 小野, 2000). 本稿では以降, 図 9(c)における三つのピー クを周波数が低い方からそれぞれピーク A，ピーク B，ピーク C と記述する.また，図 8 のような状態を NRRO が小さい場合, 図 9 のような状態を NRRO が大きい場合と記述する. なお，評価の都合上，NRRO が小さい場合 と NRRO が大きい場合の 2 状態に分類しているが, これは大きく状態が異なるタイミングを見計らってデータを 抽出したものでしかない，実際には状態は刻々と変化しており，今後より詳細な評価を行うためには，同一の主 軸回転数における経時変化を観察する検討が必要である.

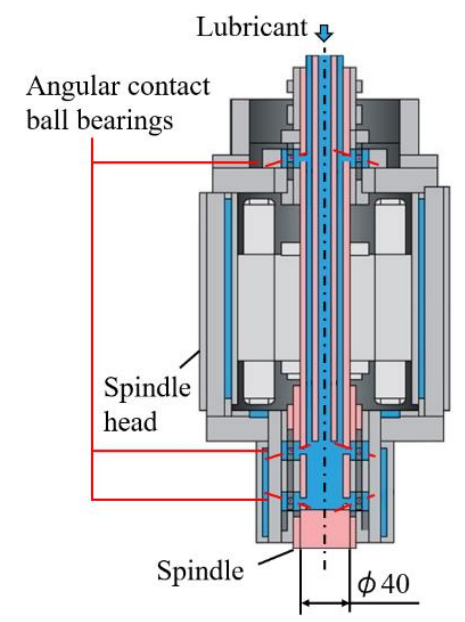

Table 2 Specification of the angular contact ball bearing. Specification of three bearings are same.

Fig. 6 Sectional view of the spindle. This spindle uses three angular contact ball bearings and underlace lubrication.

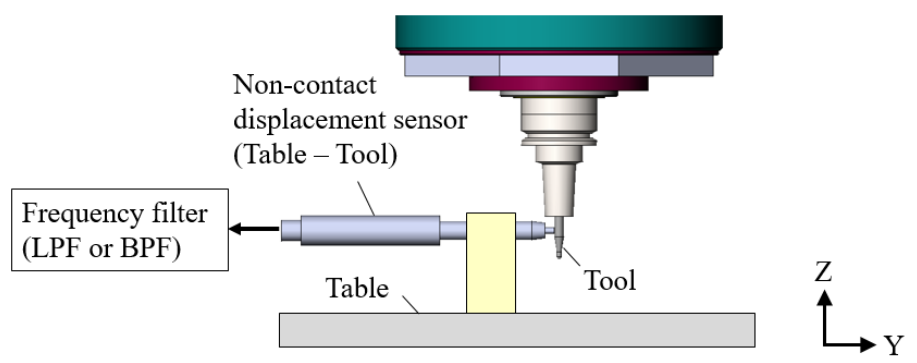

Fig. 7 NRRO measurement from the table at each spindle speed. It is possible to extract NRRO component due to rolling element revolution from tool run-out by BPF. 


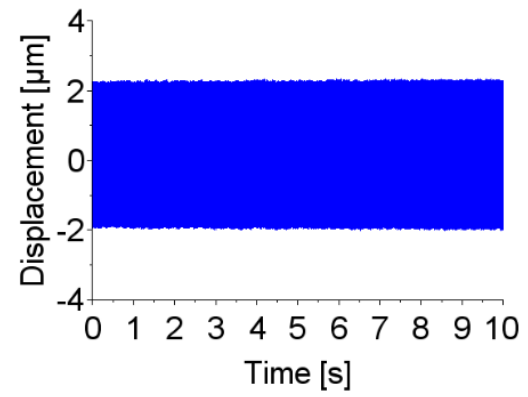

(a) LPF $1,000 \mathrm{~Hz}$

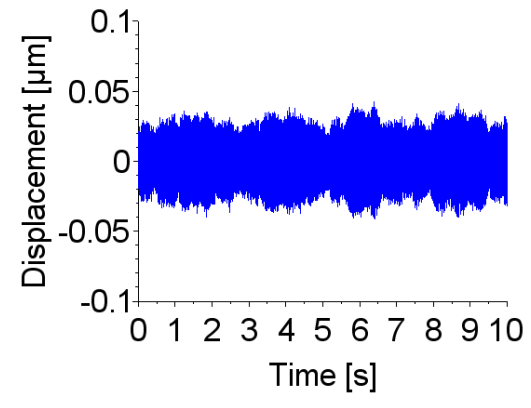

(b) BPF $225 \mathrm{~Hz}$

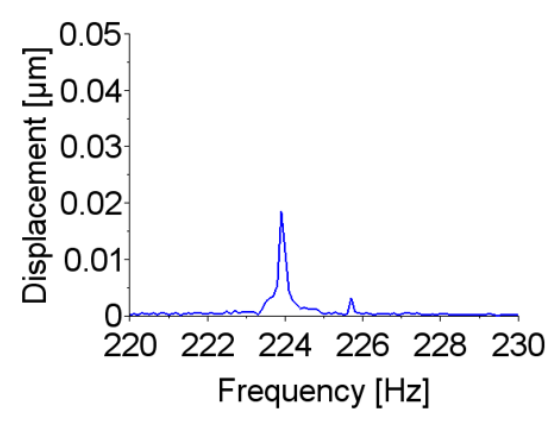

(c) Fourier spectrum

Fig. 8 Tool run-out at 30,000 $\mathrm{min}^{-1}$ (Small NRRO). These figures show state after a minute from spindle rotation start. There is one dominant peak at a frequency of NRRO due to rolling element revolution.

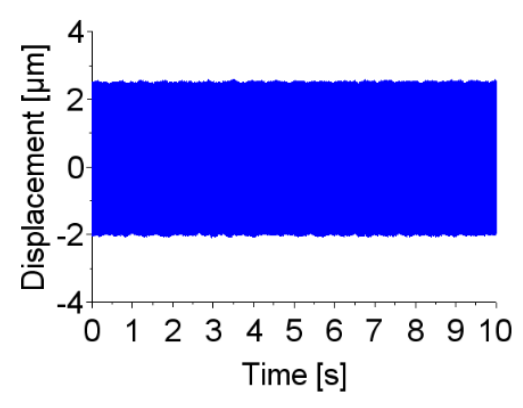

(a) LPF $1,000 \mathrm{~Hz}$

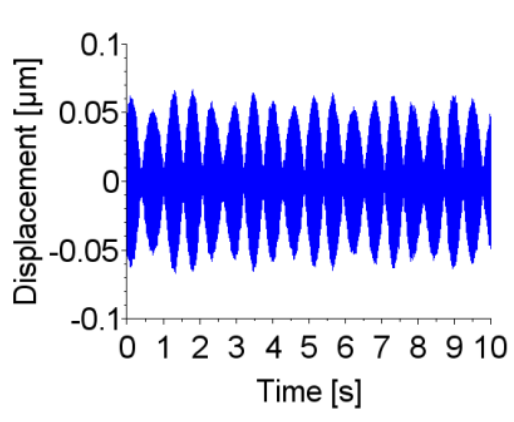

(b) BPF $225 \mathrm{~Hz}$

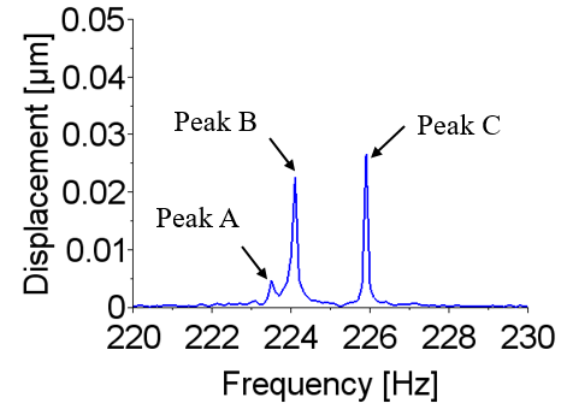

(c) Fourier spectrum

Fig. 9 Tool run-out at 30,000 $\mathrm{min}^{-1}$ (Large NRRO). These figures show state after a minute from Fig. 8 .

There are three peaks at frequencies of NRRO due to rolling element revolution.

主軸回転数を変化させた場合の各ピークの大きさおよび周波数を図 10 に示す. なお, NRRO は全振幅で評価 する必要があるため, フーリエスペクトルにおけるピークの大きさを 2 倍して評価している. 図 10(a)は三つのピ 一クを合計した大きさ, 図 10(b), (c)および(d)は各ピークの大きさを示している. NRRO が小さい場合において はピーク B が支配的であり, NRRO が大きい場合との違いはピーク A またはピーク C の大きさである. そのた め, この NRRO の状態の違いを捉えるためには，ピーク A およびピーク C の経時変化について着目する必要が あると考えられる. 図 10(e)は各ピークの周波数, 図 10(f)は式(2)によって求めた転動体公転周波数との乘離を示 している. 図 10(e)より, 各ピークの周波数はおおよそ式(2)によって求めた転動体公転周波数に沿っていることが わかるが, 図 10(f)より, 最大 $2 \%$ 程度の周波数ずれが確認でき, また主軸回転数が変化した場合の傾向は各ピー クで異なることがわかる.転動体公転周波数を決定するパラメータの一つである接触角は, 主軸回転に伴う発熱, 膨張および遠心力などによって変化する可能性があり(Abele et al., 2010), 特に発熱は主軸内部で一様ではない. よって, 各ピークは特定の一つの転がり軸受に起因するものではなく, 各転がり軸受に起因するものと推測でき る.

このように NRRO の大きさや周波数が随時変化する現象に対応するためには，加振システムは NRRO の大き さや周波数の変化に追従できなければならない.また，図 10(a)に示すように NRRO の大きさは主軸回転数とと もに増加するため, 主軸回転数が高くなるほど NRRO 低減の重要性も増すことになる.

$\mathrm{NRRO}$ は回転同期周波数以外の全ての周波数を指すが，本稿では以降，転がり軸受の転動体公転運動に起因す る NRRO を単純にNRRO と記述する. 


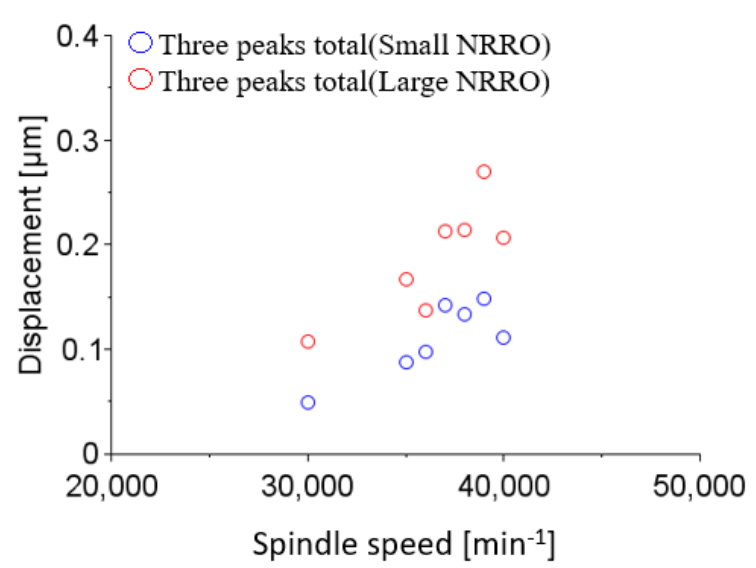

(a) Total magnitude of three peaks

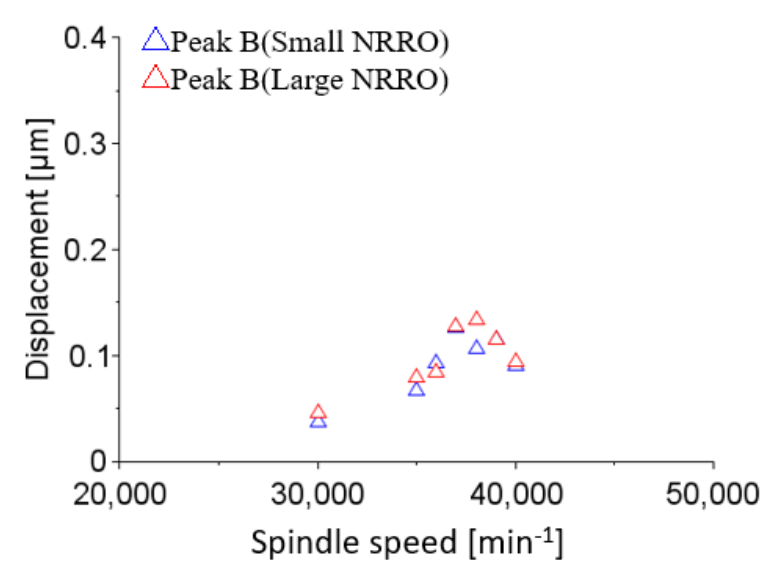

(c) Magnitude of peak B

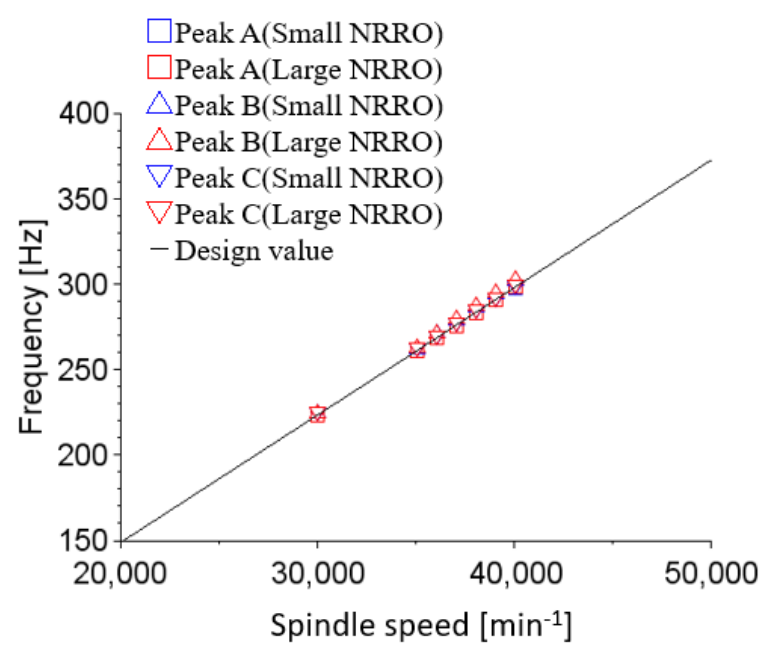

(e) Frequency of each peak

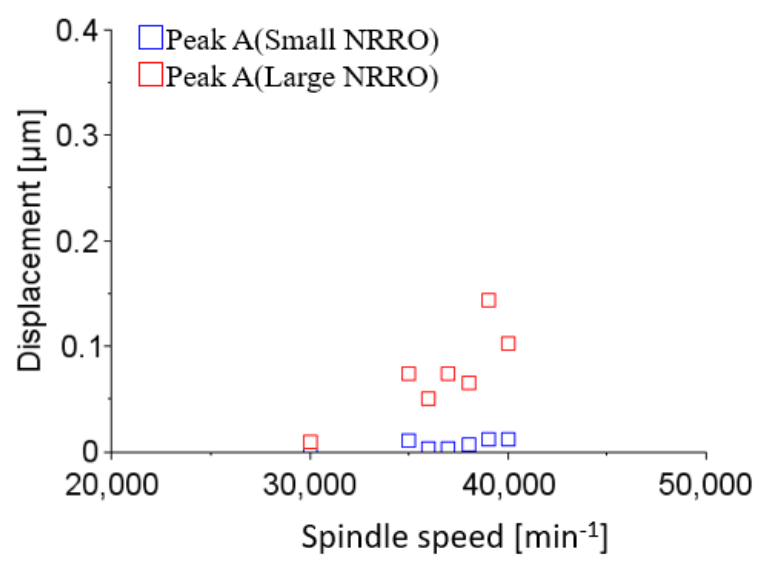

(b) Magnitude of peak A

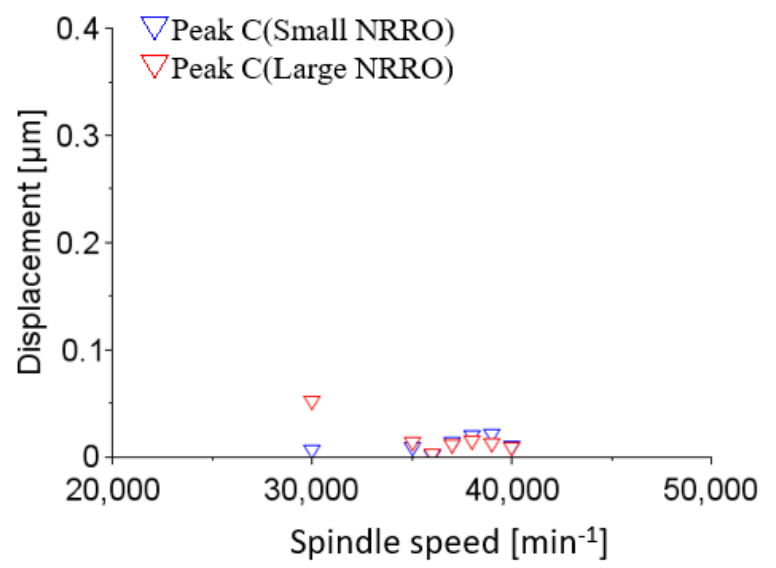

(d) Magnitude of peak C

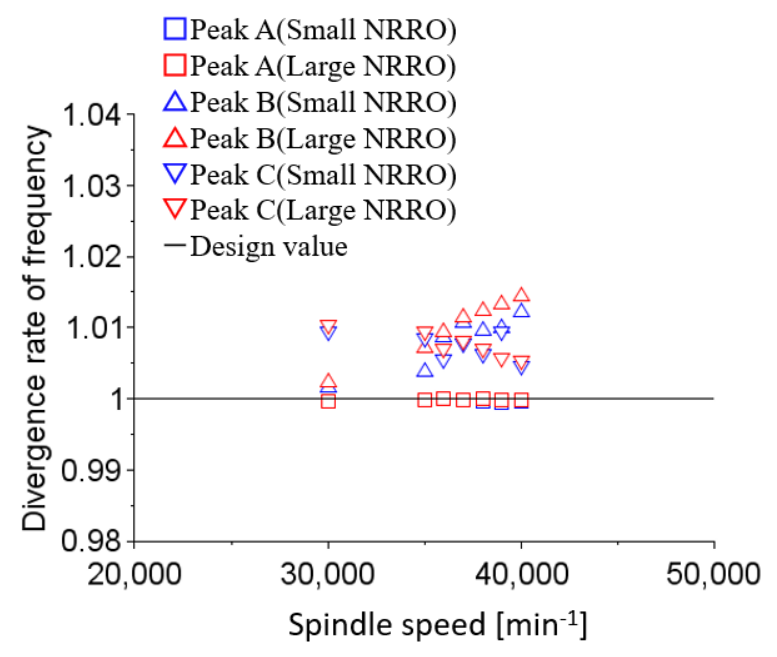

(f) Divergence rate of frequency of each peak

Fig. 10 Relationship between NRRO and spindle speed. Total magnitude of three peaks increases as spindle speed increase. Main difference between state "Small NRRO" and state "Large NRRO" is magnitude of peak A or peak C. Tendency of frequency divergence from design value depends on each peak. 


\section{NRRO による加工面影響を低減する加振システム}

\section{$4 \cdot 1$ 加振システム概要}

本研究で提案する NRRO による加工面影響を低減する加振システムの概要を図 11 に示す。まずは提案する加 振システムの有効性を確認するため，Y 軸方向の側面加工を想定した一軸の加振システムとした. 加振システム の有効性を確認した後，二軸の加振システムへと拡張する予定である。一軸の加振システムを直交に二つ配置す る構造とすれば，図 1(a)に示すように，互いに与える加振影響は小さいと考えられる．加振システムは，非接触 変位センサ，BPF，信号調整回路，リニアアンプおよび加振装置から構成される．第 3 章の測定より，NRRO は 近接した複数の周波数成分から構成され，同じ主軸回転数を維持した場合でも各ピークの大きさや周波数は変化 することが明らかになった。加振装置内のアクチュエータへの入力信号を外部で生成するシステムとした場合， これらの変化に追従するのは困難である.よって，本システムでは主軸頭に取り付けた非接触変位センサによっ て測定した工具回転振れから，BPFにより NRRO 成分を抽出し，アクチュエータへの入力信号を得ている．BPF の中心周波数は主軸回転数に応じて式(2)によって決定されるが，今回使用した BPF は中心周波数 $\pm 5 \%$ 程度の通 過帯域幅を持っているため，周波数ずれは問題なく許容できる.しかし，リニアアンプに適切な大きさの信号を 入力するためには別途ゲイン(増幅率)の調整が必要であり，また測定位置と加振位置が離れている場合は位相の 調整も必要となる.その二つの機能を持つ信号調整回路は，アナログ回路にて製作した.

本加振システムによる NRRO の加工面影響低減効果を確認するためには, 実際に加工を行うことが確実である が，まずは代替評価として通常工作物を設置するテーブル上にも非接触変位センサを用意して同様に工具回転振 れを測定し，NRRO 成分の低減効果を評価した。テーブル上に固定した非接触変位センサにより測定した工具回 転振れからある程度加工面プロファイルの推定が可能であり, テーブルを基準とした工具回転振れから NRRO 成 分を低減することができれば，実加工においても NRROの影響低減が期待できる.

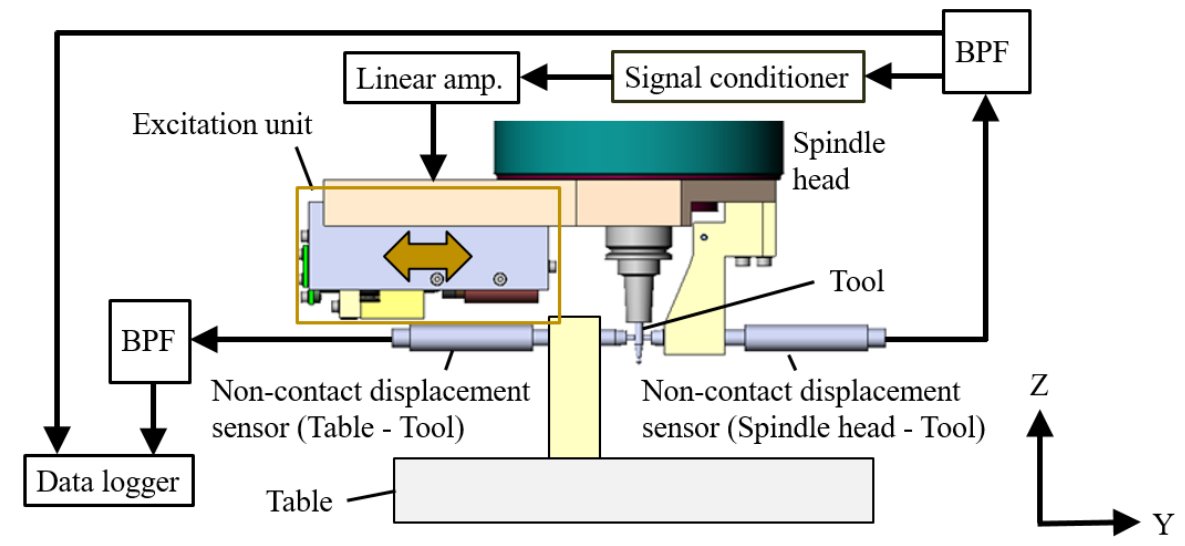

Fig. 11 Outline of an excitation system. This system consists of a non-contact displacement sensor, a BPF, a signal conditioner, a linear amp. and an excitation unit.

\section{4-2 試作した加振装置}

NRRO による加工面影響を低減する加振システムの試作にあたり，VCM を用いた加振装置を試作した。必要 な加振力および加振周波数は，主軸回転数に依存する. 主軸回転数は，仕上げ加工向けとして $30,000 \mathrm{~min}^{-1} \sim$ $50,000 \mathrm{~min}^{-1}$ の範囲を想定した. この場合，加振周波数は式(2)より， $225 \mathrm{~Hz} \sim 400 \mathrm{~Hz}$ となる. 加振装置の加振力 $F$ は，運動の第 2 法則より駆動体質量 $m$ と駆動体加速度 $a$ の積で決定されるが，質量 $m$ を主軸回転数に応じて変 化させるのは困難であるため, 加振力 $F$ は加速度 $a$ によりコントロールするものとした. 高応答アクチュエータ として代表的なものにピエゾアクチュエータがあるが，幅広い回転数に対応するためには，ストロークが課題と なる．そこで，アクティブダンパ用アクチュエータとして採用例(藤田他，1990)のある VCM を採用した. 試作し た加振装置を図 12 に示す. VCM（AVM35-HF-7，Akribis Systems）のコイルはシャフトを介して空気静圧軸受お よび板ばねによって支持されており，駆動体質量 $m$ は $0.1 \mathrm{~kg}$ である. 
試作した加振装置の加振力評価を行うため, 図 13 のように圧電形動力計(9255B, KISTLER)の上に積載し, 加 振中の反力測定を行った。 VCM の駆動には，ファンクションジェネレータ(WF1968, NF 回路設計ブロック)およ びリニアアンプ(LA640, サーボテクノ)を使用した. 図 14(a)にリニアアンプ入力電圧を変化させた場合の加振力, 図 14(b)にリニアアンプ入力電圧の周波数を変化させた場合の加振力をそれぞれ示す. 加振試験の結果, $225 \mathrm{~Hz} \sim$ $400 \mathrm{~Hz}$ の範囲でおおよそ設計值どおりの加振力が得られることを確認した.
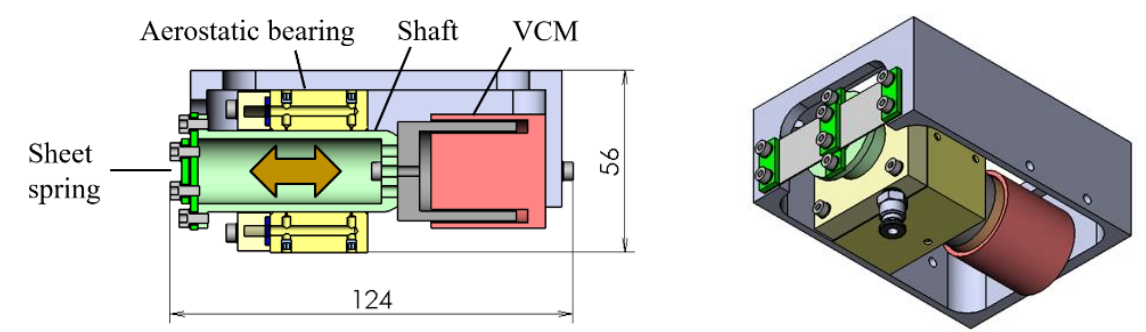

Fig. 12 A developed excitation unit. This unit consists of a VCM, a shaft, an aerostatic bearing and a sheet spring.

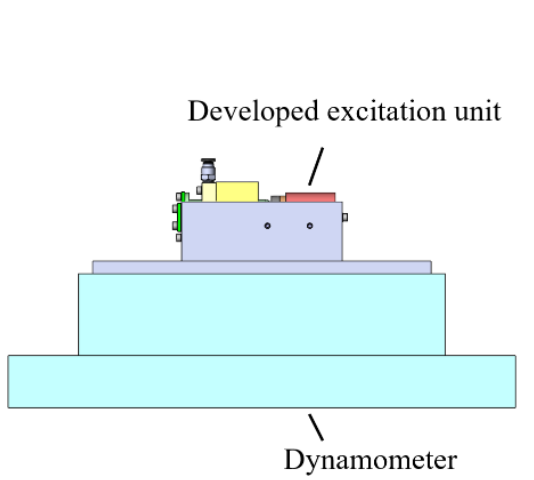

Fig. 13 Excitation force confirmation of the developed excitation unit. Excitation force is measured with a dynamometer.

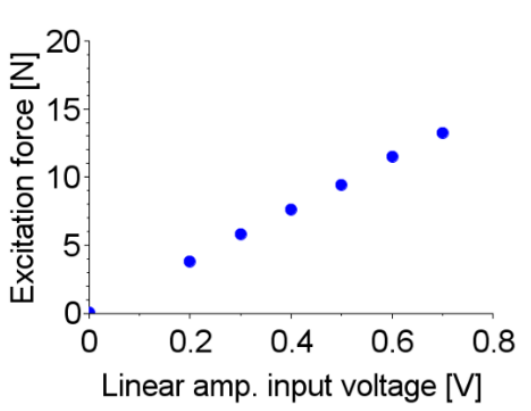

(a) Linear amp. input voltage response

(Linear amp. input frequency $340 \mathrm{~Hz}$ )

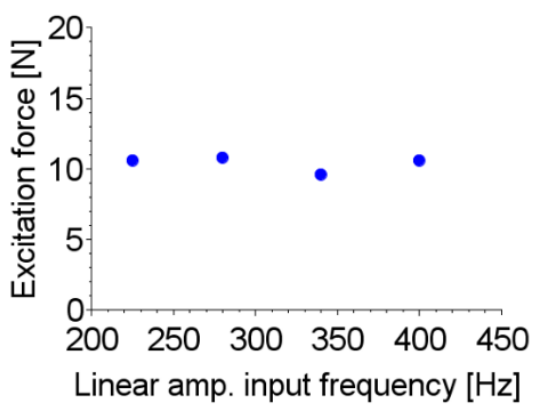

(b) Excitation frequency response

(Linear amp. input voltage $0.5 \mathrm{~V}$ )

Fig. 14 Excitation performance of the developed excitation unit. The excitation unit has high linearity and response.

\section{$4 \cdot 3$ 試作した加振システムおよびNRRO 低減のシミュレーション}

試作した加振システムを図 15 に示す. 試作した加振装置および入力信号を得るための非接触変位センサを立 て形マシニングセンタの主軸頭に取り付け，評価基準となる非接触変位センサを同じく立て形マシニングセンタ のテーブル上に固定している. 試作した加振システムを用いてテーブルを基準とした工具回転振れから NRRO 成 分を低減可能であるか確認するため, シミュレーションを行った. 図 16 にブロック図を示寸. 主軸頭に取り付け た非接触変位センサによって測定された工具回転振れ $(x 1)$ は, 電圧 $(e 1)$ として出力され, BPF によって NRRO 成 分 $(e 2)$ が抽出される. その後, 信号調整回路にて加振指令 $(e 3)$ に変換され, 加振装置に入力される. 加振 $(x 4)$ によ って NRRO 成分が低減されたテーブル基準の工具回転振れ(x5)は，テーブル上に固定した非接触変位センサによ って測定, 電圧 $(e 4)$ として出力され, BPF によってNRRO 成分(e5)が抽出される. 変位 $(x 6)$ として評価する場合は, 逆変換すればよい．システムデザインとしては，主軸頭に取り付けた非接触変位センサは加振影響を受けないよ うになっているが，実際にはセンサ取り付け部の剛性などの理由により，わずかに影響( $x 3$ )を受ける. その影響は フィードバック回路として表現している. 伝達関数 $G 2, G 4$ および $G 5$ はスイープ信号を入力した場合の周波数 応答から実験的に求めた. $G 4$ および $G 5$ はどちらも加振装置であるが，影響を与える先が異なるということであ る. $G 1$ は非接触変位センサの換算係数，G3 は信号調整回路のゲイン(増幅率)である．信号調整回路は位相調整 の機能も持っているが，今回は調整対象としていない．今後，必要に応じて調整を実施する予定である. 入力信 号 $(x 1$ および $x 2)$ は，実機にて測定した $30,000 \mathrm{~min}^{-1}$ の工具回転振れデータを使用した. 


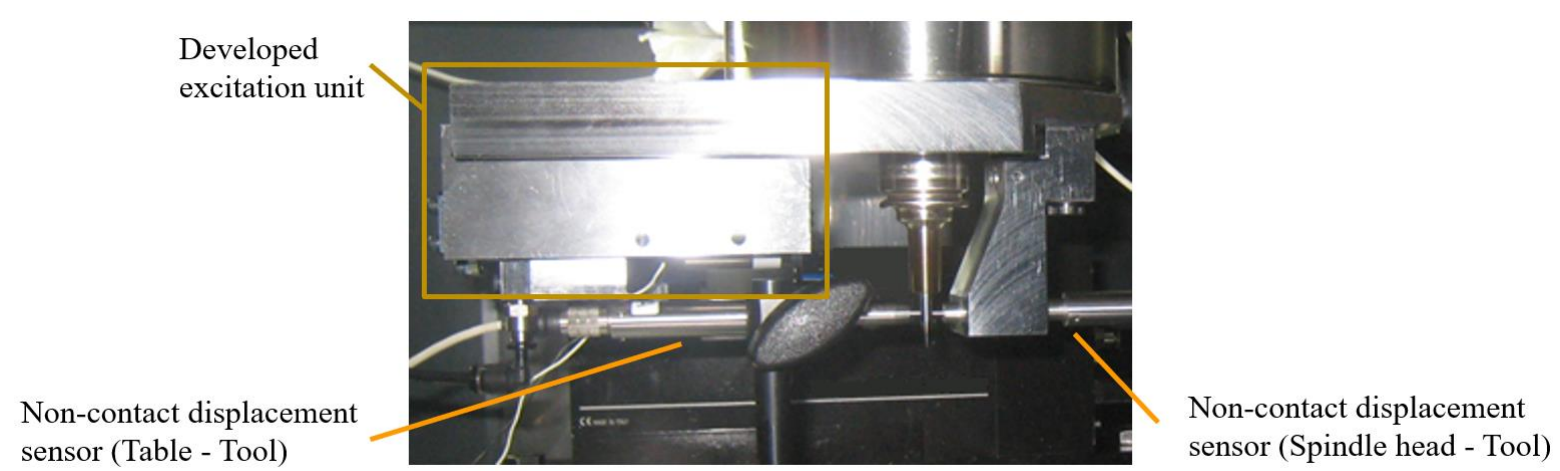

Fig.15 A developed excitation system. This system was installed to the spindle head of vertical machining center.

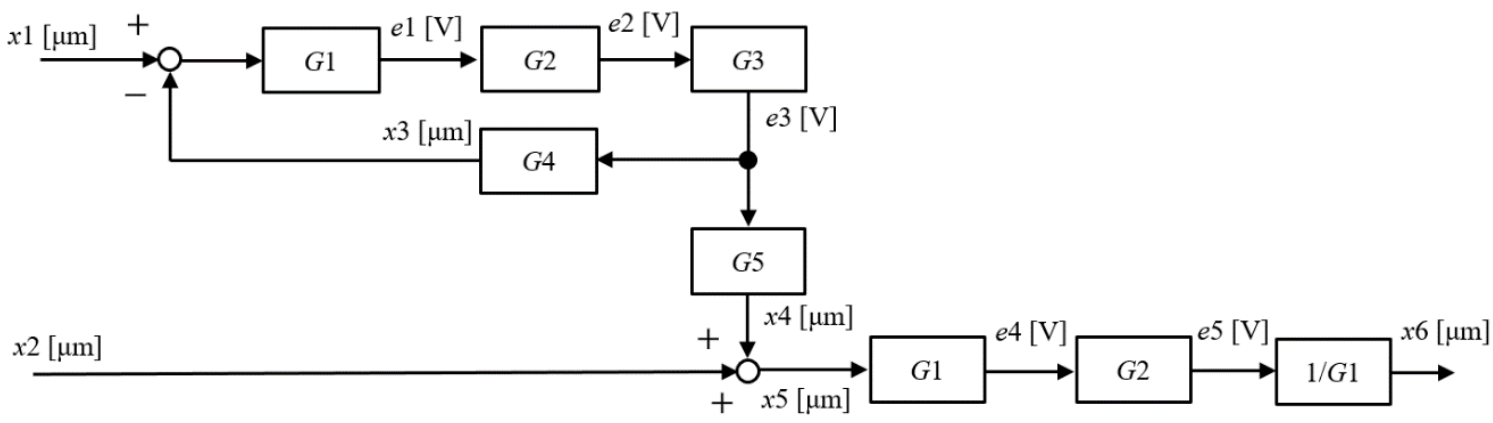

- Displacement

$x 1$ : Tool run-out (Spindle head - Tool), x2: Tool run-out (Table - Tool), x3: Excitation effect (Spindle head - Tool), $x 4$ : Excitation effect (Table - Tool), $x 5$ : Tool run-out with excitation (Table - Tool), $x 6$ : NRRO with excitation (Table - Tool)

- Voltage

$e$ 1: Tool run-out (Spindle head - Tool), e2:NRRO (Spindle head-Tool), e3: Excitation command,

$e 4$ : Tool run-out with excitation (Table - Tool), e5: NRRO with excitation (Table - Tool)

- Transfer function

G1: Non-contact displacement sensor (Input: Displacement, Output: Voltage),

G2: BPF 225Hz(Input: Tool run-out, Output: NRRO),

G3: Gain (Input: NRRO, Output: Excitation command),

G4: Excitation unit (Input: Excitation command, Output: Excitation effect (Spindle head - Tool)),

G5: Excitation unit (Input: Excitation command, Output: Excitation effect (Table - Tool))

Fig. 16 Block diagram for simulation of NRRO reduction at 30,000 $\mathrm{min}^{-1}$. Transfer function (G2, G4 and G5) was determined experimentally by frequency response. Input signals $(x 1$ and $x 2)$ are actual tool run-out measured in advance. 
図 17 にシミュレーション結果を示寸. 実機にて測定した工具回転振れにシミュレーションした加振信号を加 えることにより，図 17(a)に示すように，NRRO に該当するピークの大きさを約 50 \%に低減可能であることを確 認した．ゲインを大きくするほど加振力は強くなり, 結果として図 17(b)に示すように NRRO 低減効果も高くな る.しかし，過大に設定すると逆に悪影響をおよぼし始める。シミュレーションにおいては，ゲインの設定值が 24 を超えると $250 \mathrm{~Hz}$ 付近に意図しない振動が発生したため, $30,000 \mathrm{~min}^{-1}$ におけるゲインの設定值は 20 とした. この原因の一因は，前述したように加振力が強くなると加振装置の入力源となるセンサに影響を与えてしまうこ とにあり，シミュレーション上は，該当部を削除することでゲインの向上が可能である.

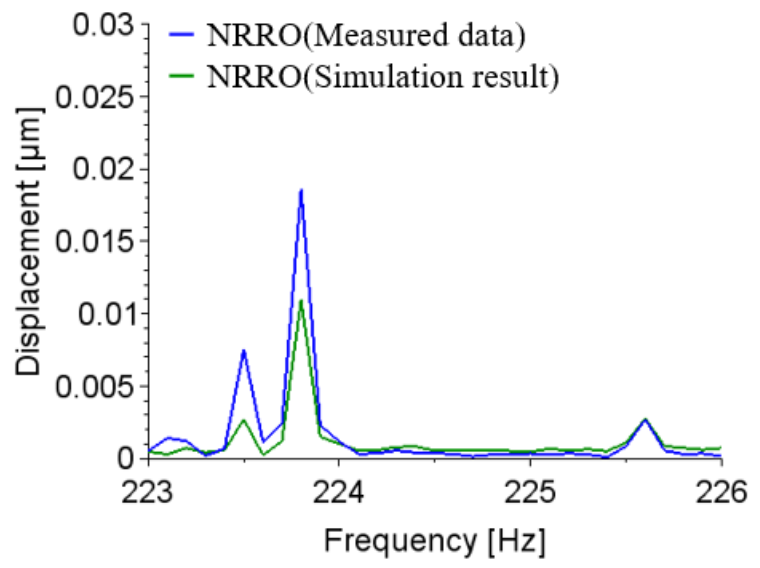

(a) Fourier spectrum (Gain: 20)

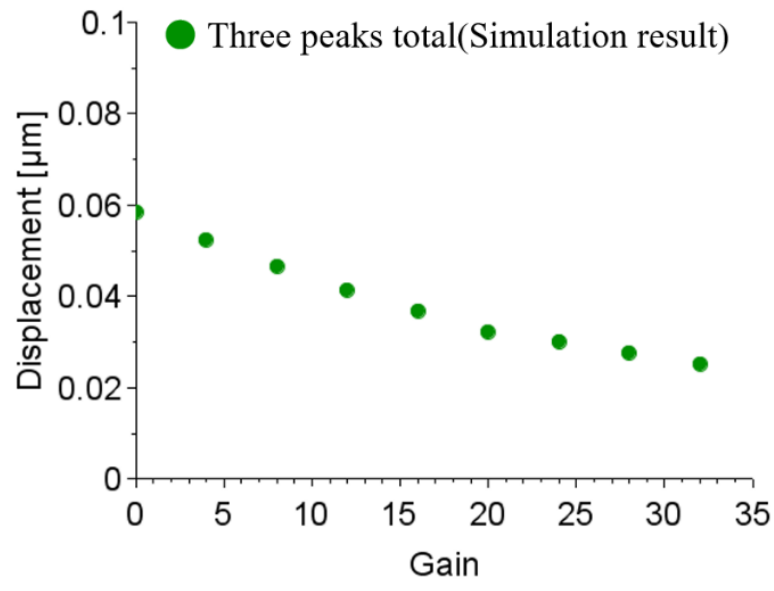

(b) Gain response

Fig. 17 Simulation results of NRRO reduction at $30,000 \mathrm{~min}^{-1}$.

NRRO reduced to approximately $50 \%$ by excitation.

\section{$4 \cdot 4$ 試作した加振システムによるNRRO の低減効果}

シミュレーションと同じくテーブルを基準とした工具回転振れから NRRO 成分を低減可能であることを確認 するため, 試作した加振システムを用いて主軸回転数 30,000 $\mathrm{min}^{-1}$ かつ第 3 章における NRRO が小さい場合につ いて加振実験を行った. 図 18(a)に加振前の NRRO, 図 18(b)に加振中の NRRO, 図 18(c)に各フーリエスペクトル をそれぞれ示寸. 加振により，NRRO を約 30 \%に低減可能であることを確認した. さらに，主軸回転数 35,000 $\mathrm{min}^{-1}, 40,000 \mathrm{~min}^{-1}$, 第 3 章における NRRO が小さい場合およびNRRO が大きい場合についても加振実験を行った. ゲインの設定值は 20 を基準にしているが, 発振状態となった条件についてはゲインの設定值を下げている. 各条 件におけるゲインの設定值を表 3 に示寸．図 19(a)に三つのピークを合計した大きさ，図 19(b)，(c)および(d)に各 ピークの大きさをそれぞれ示す. NRRO が小さい場合においては，図19(a)に示すように，いずれの条件において も NRRO を低減可能であることを確認した。 しかし, 主軸回転数 $35,000 \mathrm{~min}^{-1}$ および 40,000 $\mathrm{min}^{-1}$ においては, 30,000 $\mathrm{min}^{-1}$ 程の NRRO の低減効果は得られなかった。これは，主軸頭を基準とした工具回転振れの NRRO とテ 一ブルを基準とした工具回転振れの NRRO で各ピークの大きさのバランスが異なることが原因であると考えら れる. NRRO が大きい場合については, 図 19(a)に示すように，30,000 $\mathrm{min}^{-1}$ では NRRO の低減効果が確認出来た が，35,000 $\mathrm{min}^{-1}$ 以上では加振により NRRO が増大寸るという結果となった. 図 19(b), (c)および(d)にてピーク毎 の加振影響を観察すると, ピーク B は加振によって低減されているが, ピーク A は増大しており, 結果として三 つのピークを合計した大きさが増大していることがわかる.

本加振システムは, 基本的に転がり軸受の転動体公転運動に起因する NRRO を単一の振動とみなして低減しよ うとするものである. しかし今回の結果から, さらなる低減のためには少なくとも二つ以上のピークについて別々 に考慮しなければならないことがわかった。

なお，第 3 章での測定に対して全体的に NRRO が大きくなっているのは，主軸頭先端部に重量物である加振装 置を取り付けたことにより，主軸頭およびその周辺部が振動しやすくなったためである．この点を改善するため には，今後加振装置は可能な限り小さく，かつ軽量なものとする必要がある. 


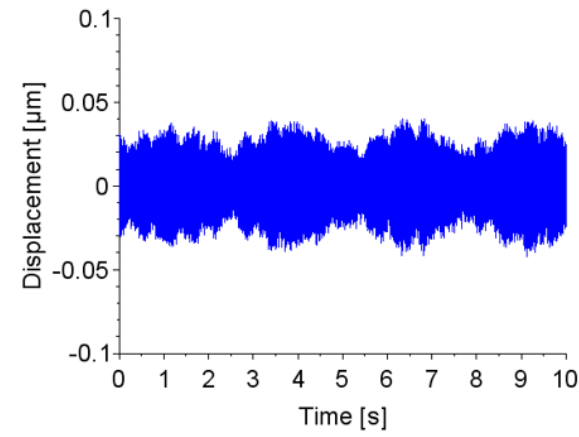

(a) NRRO without excitation

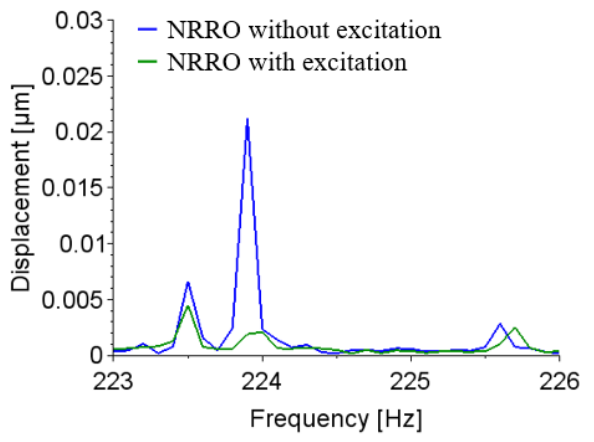

(c) Fourier spectrum

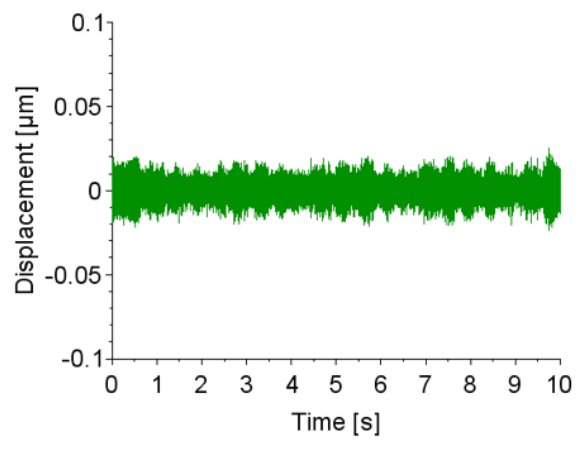

(b) NRRO with excitation

Fig. 18 NRRO reduction result by the developed excitation system at 30,000 $\mathrm{min}^{-1}$ (Small NRRO). NRRO reduced to approximately $30 \%$ by excitation.

Table 3 Gain parameter setting. It was decided for each spindle speed and NRRO state.

\begin{tabular}{|c|c|c|}
\hline \multirow{2}{*}{ Spindle specd $\left[\mathrm{min}^{-1}\right]$} & \multicolumn{2}{|c|}{ NRRO } \\
\cline { 2 - 3 } & Small & Large \\
\hline 30,000 & 20 & 20 \\
\hline 35,000 & 20 & 20 \\
\hline 40,000 & 20 & 8 \\
\hline
\end{tabular}




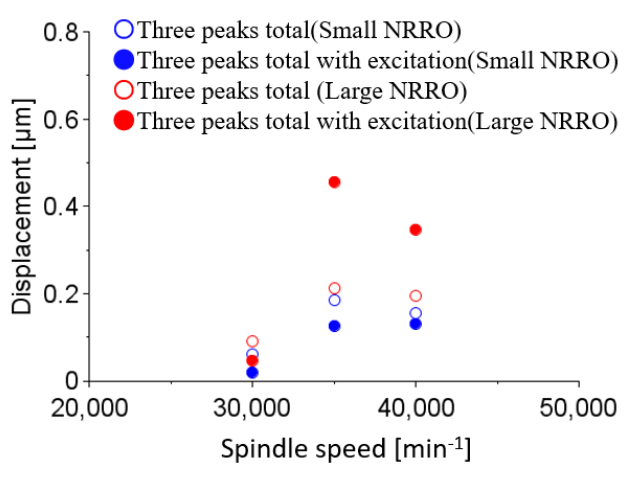

(a) Total magnitude of three peaks

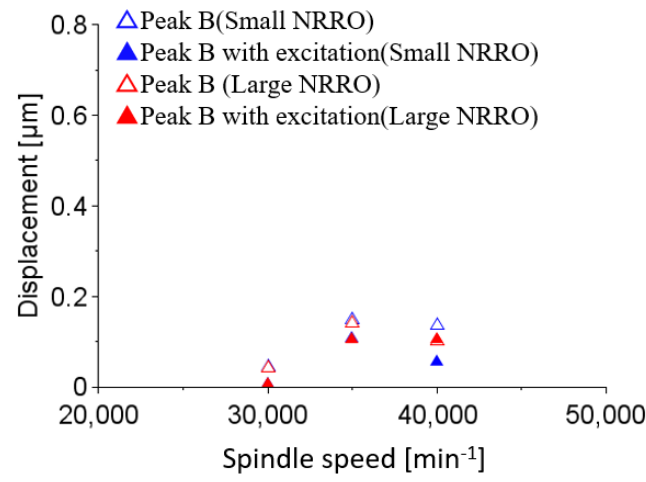

(c) Magnitude of peak B

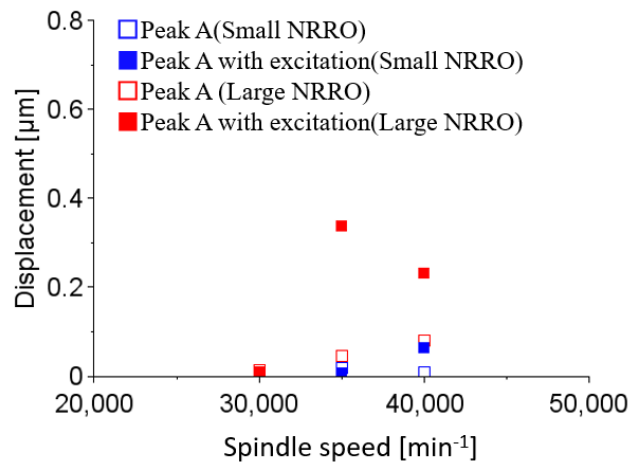

(b) Magnitude of peak A

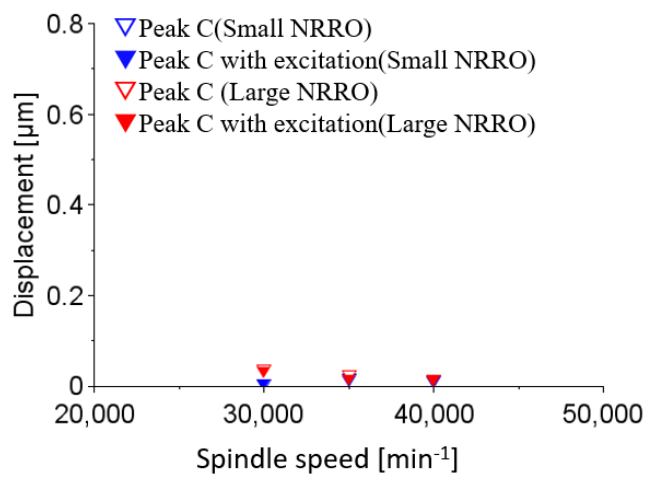

(d) Magnitude of peak C

Fig. 19 NRRO reduction result by the developed excitation system. Although NRRO in "Small NRRO" state reduced by excitation, NRRO in "Large NRRO" state increased by excitation. Because the developed system cannot reduce the peak $\mathrm{A}$ and $\mathrm{B}$ simultaneously.

\section{5. 結 論}

本稿では工作機械用転がり軸受主軸の工具回転非同期振れによる加工面影響を低減する加振システムを試作し， 以下の結論を得た.

・測定した工具回転振れの中から NRRO 成分を抽出し, 主軸頭に付与した加振装置を用いて相対振動を励起す ることでテーブルー工具間の相対変位から NRRO 成分を低減可能なシステムを提案した.

・上記加振システムの試作を行い, 主軸回転数 $30,000 \mathrm{~min}^{-1}$ において NRRO を低減可能であることを確認した. しかし，それ以外の主軸回転数ではNRRO の低減効果は得られなかった.

・工作機械用転がり軸受主軸の NRRO は単一の周波数ピークであるとは限らず，また各ピークの大きさ，周波 数は同じ主軸回転数を維持した場合でも変化する. そのため, NRRO 低減のためには各々のピークについて 別々に考慮する必要がある.

\section{文献}

Abele, E., Altintas, Y. and Brecher, C., Machine tool spindle units, CIRP Annals, Vol.59, No.2 (2010), pp.781-802.

藤田隆史, 福久聡, 村井信義, 高橋良典, 片山和喜, リニアモータを用いたアクティブ微振動除振装置の研究, 日本機械学会論文集 C 編, Vol.56, No.523 (1990), pp.628-633.

Kleinwort, R., Platz, J. and Zaeh, M. F., Adaptive active vibration control for machine tools with highly position-dependent dynamics, International Journal of Automation Technology, Vol.12, No.5 (2018), pp.631-641.

是田規之, 江川庸夫, 黒田基文, 渡辺健, 井伊良治, ボールエンドミル加工における表面粗さの生成過程の解析, 精密工学会誌, Vol.59, No.9 (1993), pp.1537-1542. 
Monnin, J., Kuster, F. and Wegener, K., Modeling errors influencing active structural methods for chatter mitigation in milling process, Procedia CIRP, Vol.14 (2014), pp.494-499.

中野寛，高原弘樹，河合謙吾，多重動吸振器を用いたエンドミル加工時の強制びびりおよび再生びびり振動の抑 制対策，日本機械学会論文集，Vol.80, No.812 (2014), DOI: 10.1299/transjsme.2014dr0098.

根深鉄平, 田中秀岳, 柳和久, 小径エンドミルの回転振れ軌跡と切れ刃プロファイルに基づく加工面性状の推定 (第 1 報) -解析モデルと回転振れ成分の転写性-，精密工学会誌，Vol.75, No.5 (2009), pp.645-649.

野口昭治，小野京右，磁気ディスクスピンドルモータ用玉軸受の回転非同期振れの低減(第 3 報，回転非同期振れ に及ぼす潤滑の影響)，日本機械学会論文集 C 編，Vol.66, No.642 (2000), pp.648-653.

野口昭治, 畔柳雄太，玉軸受の転動体公転挙動に及ぼすラジアル荷重の影響，日本機械学会論文集 C 編，Vol.73， No.735 (2007), pp.3063-3068.

野口昭治，佐藤優太，野木高，金田徹，玉軸受単体の回転非同期振れに及ぼす傾斜誤差の影響，日本機械学会論 文集 C 編, Vol.78, No.785 (2012), pp.272-281.

野口昭治，金田徹，2 つの玉軸受で支持された軸の回転精度における軸受取付誤差と外輪取付位相の影響，設計 工学, Vol.52, No.10 (2017), pp.629-638.

Oda, M., Torihara, T., Kondo, E. and Kumazawa, N., Feasibility study of a hybrid spindle system with ball and active magnetic bearings for quadrant glitch compensation during end milling, International Journal of Automation Technology, Vol.13, No.3 (2019), pp.432-439.

van Dijk, N., Active chatter control in high-speed milling processes, Doct. diss.: Eindhoven University of Technology (2011).

\section{References}

Abele, E., Altintas, Y. and Brecher, C., Machine tool spindle units, CIRP Annals, Vol.59, No.2 (2010), pp.781-802.

Fujita, T., Fukushima, S., Murai, N., Takahashi, Y. and Katayama, K., Active microtremor isolation system using linear motors, Transactions of the Japan Society of Mechanical Engineers, Series C, Vol.56, No.523 (1990), pp.628-633 (in Japanese).

Kleinwort, R., Platz, J. and Zaeh, M. F., Adaptive active vibration control for machine tools with highly position-dependent dynamics, International Journal of Automation Technology, Vol.12, No.5 (2018), pp.631-641.

Koreta, N., Egawa, T., Kuroda, M., Watanabe, K. and Ii, Y., Analysis of surface roughness generation by ball endmill machining, Journal of the JSPE, Vol.59, No.9 (1993), pp.1537-1542 (in Japanese).

Monnin, J., Kuster, F. and Wegener, K., Modeling errors influencing active structural methods for chatter mitigation in milling process, Procedia CIRP, Vol.14 (2014), pp.494-499.

Nakano, Y., Takahara, H. and Kawai, K., The countermeasure against forced and regenerative chatter in end milling process with multiple dynamic absorbers, Transactions of the JSME (in Japanese), Vol.80, No.812 (2014), DOI: 10.1299/transjsme.2014dr0098.

Nebuka, T., Tanaka, H. and Yanagi, K., Estimation of machined surface texture being based on cutter run-out trajectory and cutting edge profile of small diameter end-mill (1st report) -analytical model and geometrical transfer of run-out components-, Journal of the JSPE, Vol.75, No.5 (2009), pp.645-649 (in Japanese).

Noguchi, S. and Ono, K., Reduction of NRRO in a ball bearing for HDD spindle motors (3rd report, influence of lubrication on NRRO of a ball bearing), Transactions of the Japan Society of Mechanical Engineers, Series C, Vol.66, No.642 (2000), pp.648-653 (in Japanese).

Noguchi, S. and Azeyanagi, Y., The Influence of radial loads on the ball revolution behavior in ball bearing, Transactions of the Japan Society of Mechanical Engineers, Series C, Vol.73, No.735 (2007), pp.3063-3068 (in Japanese).

Noguchi, S., Sato, Y., Nogi, T. and Kanada, T., Influence of inclination error on non repetitive run-out of the single ball bearing, Transactions of the Japan Society of Mechanical Engineers, Series C, Vol.78, No.785 (2012), pp.272-281 (in Japanese).

Noguchi, S. and Kanada, T., Effect of bearing attachment error and phase of attachment in outer ring to the rotation accuracy of shaft, Journal of Japan Society for Design Engineering, Vol.52, No.10 (2017), pp.629-638 (in Japanese).

Oda, M., Torihara, T., Kondo, E. and Kumazawa, N., Feasibility study of a hybrid spindle system with ball and active magnetic bearings for quadrant glitch compensation during end milling, International Journal of Automation Technology, Vol.13, No.3 (2019), pp.432-439.

van Dijk, N., Active chatter control in high-speed milling processes, Doct. diss.: Eindhoven University of Technology (2011). 